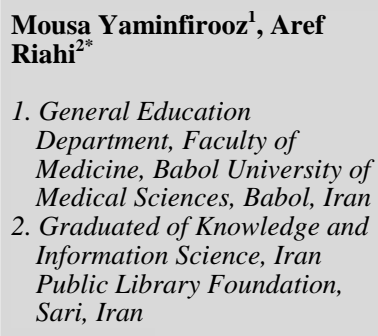

\section{Scientific Production of Iran in the Field of Occupational and Professional Health and Determined Its Level in the Word During 2000-2016}

Received:15 Jul. 2017; Accepted:4 Jan. 2018

Introduction: The status and role of each country in scientific outputs in specific fields may indicate the potential and its performance in promoting and improving that particular issue. This study aimed to investigate Iranian scientific production in the field of Occupational and Professional Health and determine its level in Region and the World.

Methods: This is Survey-Descriptive study with Scientometrics approach. Population study includes 1787 scientific articles and papers in the field of Occupational and Professional health which published and indexed in Scopus database during 2000-2016. We use SPSS, NodeXL and VOSviewer to analysis data and design graphs.

Findings: Finding shows that Iranian scientific outputs in the field of Occupational and Professional Health increase from 3 in 2000 to 266 in 2016 and have 34\% growth every year. Also we fended that Tehran University of Medical Science and United States as the most important center and co-worker in publishing scientific production.

Conclusion Although Iranian scientific production in the recent years have an acceptable increasing, but totally Iranian place of scientific production in the field of Occupational and Professional Health were not suitable in the world. Also the quality of published articles was in medium level. Making policy and Tacking good decision related to growth of quality and quantity of scientific papers by increasing level of scientific collaboration and use all internal potential seems necessary.

Keywords: Health, Occupational Health, Professional Health, Scientific Production, Scientific Database, Scopus, Iran 


\section{ارزيابى توليدات علمى حوزه بهداشت كار و حرفهاى و تعيين جايكًاه بين المللى جمهورى اسلامى ايران در پايكًاه اطلاعاتى اسكويوس

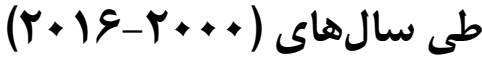

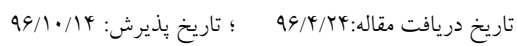

مقدمه: تعيين جايخاه هر كشورى در عرصه توليد علم و در حوزههاى موضوعى كوناكون، مسىتوانــ نشـان دهنـــه ميـزان

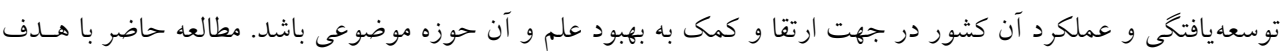
ارزيابى توليدات علمى و نيز تعيين جايگاه منطقهاى و جهانى جمهورى اسلامى ايران در حسوزه بهداشـت كـار و حرفـهاى صورت كرفته است روش يزوهش: مطالعه حاضر به لحاظ هدف كاربردى و به روش ييمايشى توصيفى (با رويكرد علم سنجى) صورت كرفته است. جامعه آمارى مطالعه حاضر را IVAV مقاله و مدرك علمى نمايه شده يزووهشخران جمهورى اسلامى ايسران در حـوزه

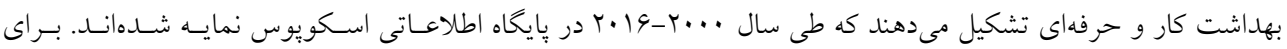
تجزيه و تحليل اطلاعات و ترسيم شكل ها، از نرمافزارهاى SPSS، و VOSviewer NodeXL استفاده شده است. يافته ها: يافتهها نشان داد كه تعداد مقالات حوزه بهداشت كار و حرفهاى جمهورى اسلامى ايران از ب مورد در سـال ب...

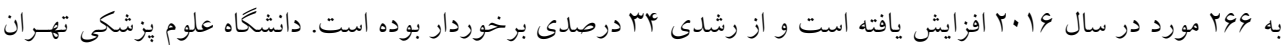
و ايالات متحده امريكا به ترتيب به عنوان يرتوليدترين مركز داخلى و مهمترين شـريك علمسى يزوهشــران حـوزه مـورد بررسى شناسايى شدهاند. بحث و نتيجه گيرى: هر جند توليدات جمهورى اسلامى ايران در حوزه مورد بررسى طى سالهـاى اخيسر از رشـد مثبتى برخوردار بوده است، ولى به طور كلى جايگاه جهانى توليدات علمى حوزه بهداشت كار و حرفهاى كشورمان در وضسعيت قابل قبولى قرار ندارد. كيفيت مقالات منتشر شده جمهورى اسلامى ايـران نيـز در وضـعيت متوسـطى قـرار داشـهـه اسـت. سياست گذارىها و برنامهريزىهاى مناسب جهت ارتقاى سطح كمى و كيفى مقالات ايرانى با گسترش همكارىهاى علمى بين المللى و استفاده از ظرفيتهاى داخلى و حمايت يزوهشخران و متخصصان اين حوزه لازم و ضرورى بنظر مىرسد. كلمات كليدى: بهداشت، بهداشت كار، بهداشت حرفهاى، توليدات علمى، اسكويوس، ايران

موسى يمين فيروز'، عارف رياحى r* 'استاديار، كروه آموزش عمومى، دانشكيد

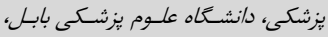
بابل، ايران

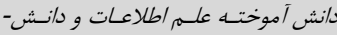

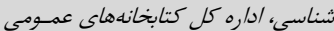
استان مازندران 
بهداشت حرفهاى كشورمان در تمامى ابعاد، از اقدامات، دستاوردها

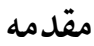

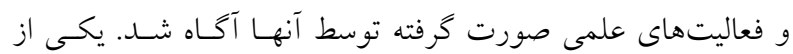

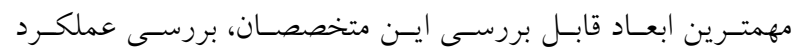

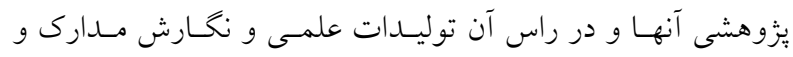

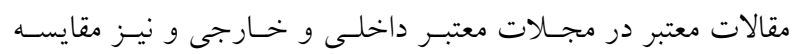
دستاوردهاى آنها در سطح بين المللى مى باشد. بعلاوه، تعيين جايخاه

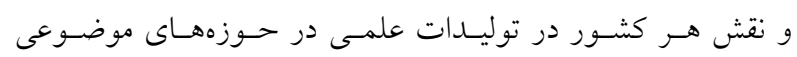

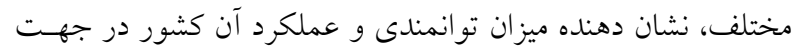

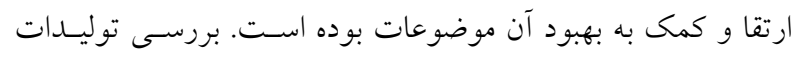

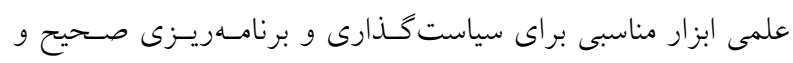

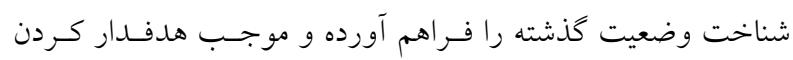

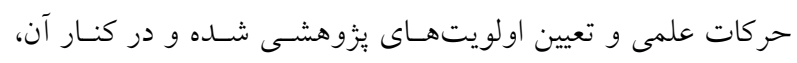

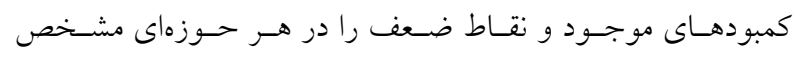

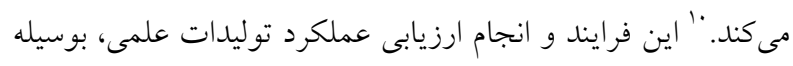

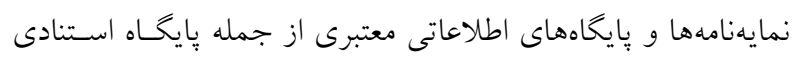
اسكويوس قابل بررسى و رويت است.

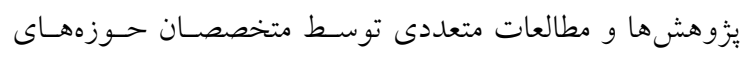

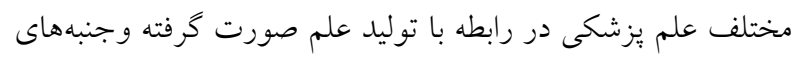

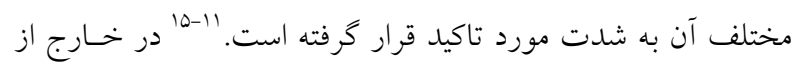

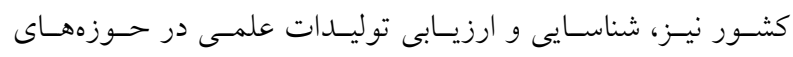

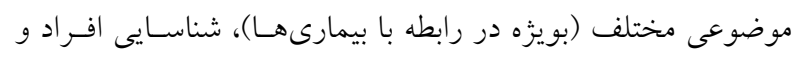

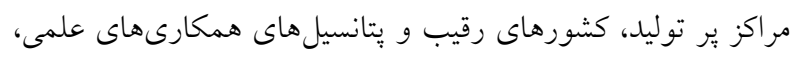

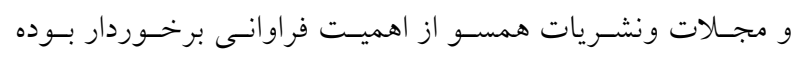

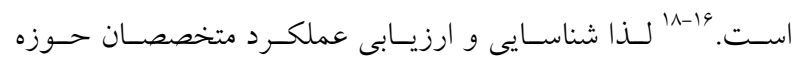

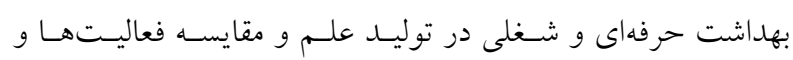

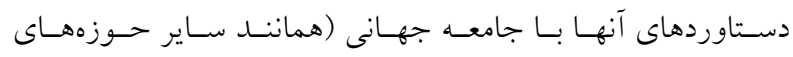

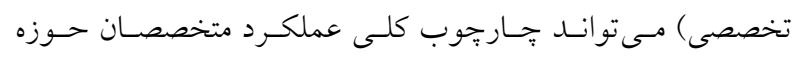

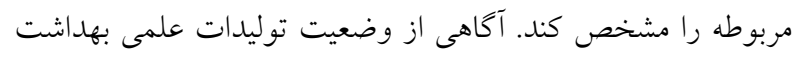

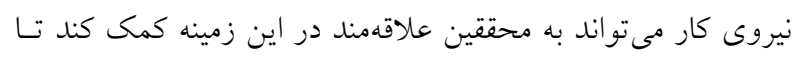

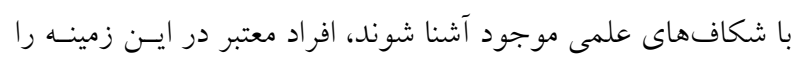

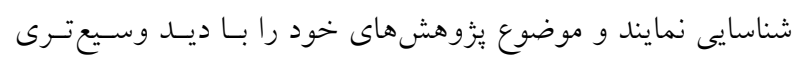

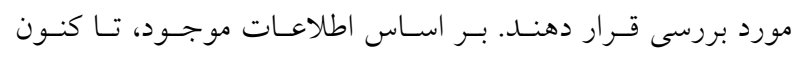

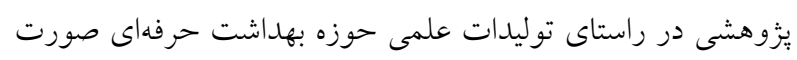

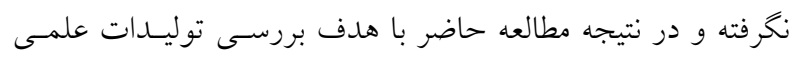

نيروى كار به عنوان عامل انسانى جهت استفاده از فناورى برتر،

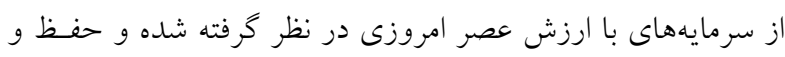
ارتقاى توانيىهاى جسمانى و روانى آن به عنوان نيروى مولد محور

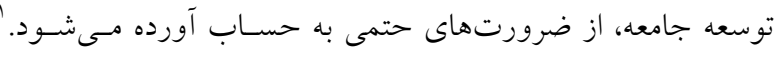

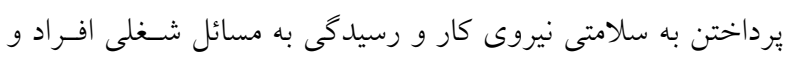

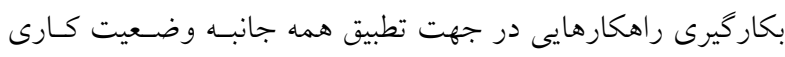

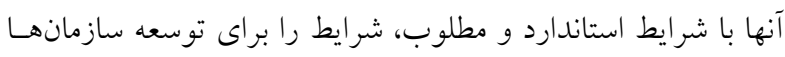

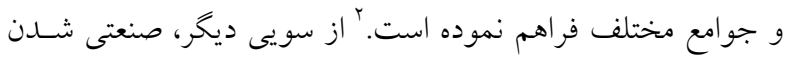

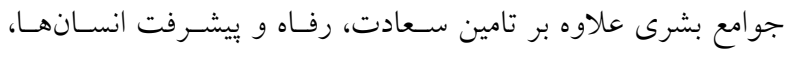

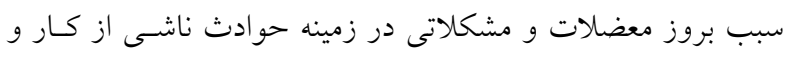

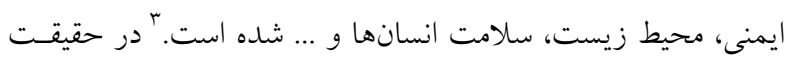

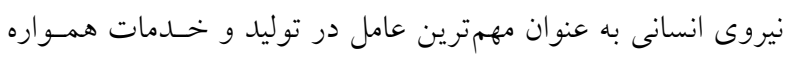

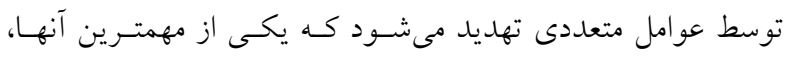

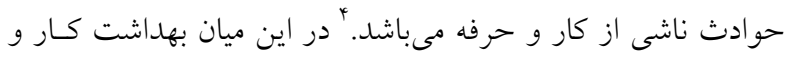

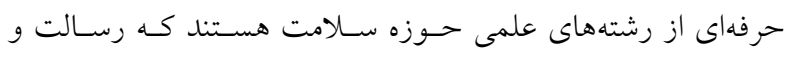

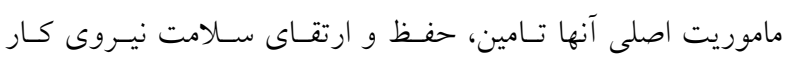

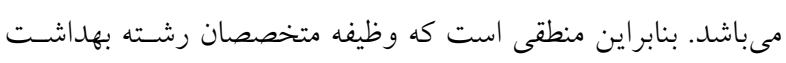

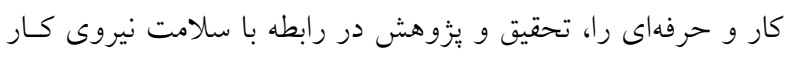

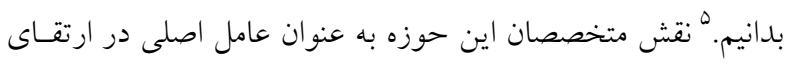

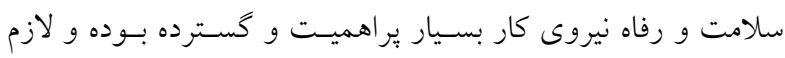

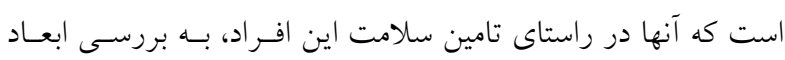
مختلف سلامت و بهاداشت شغلى و حرفهاى بيردازند.

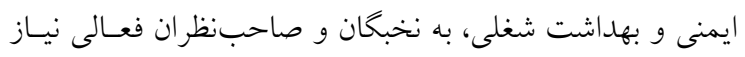

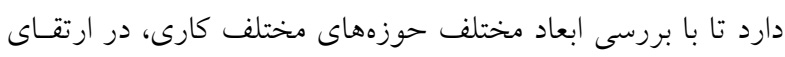

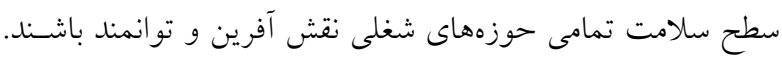

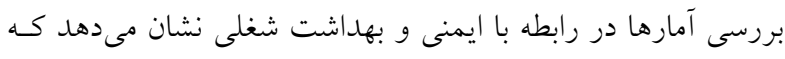

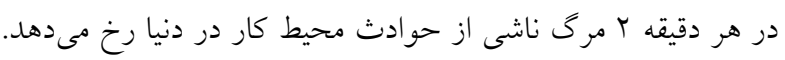

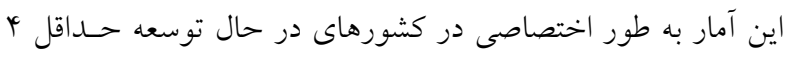

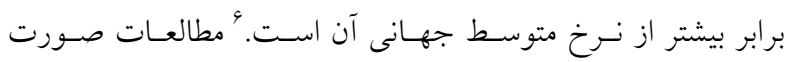

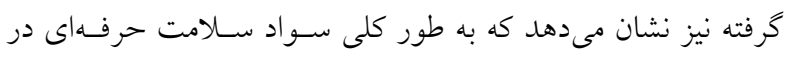

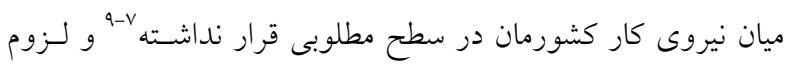

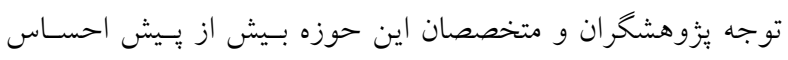

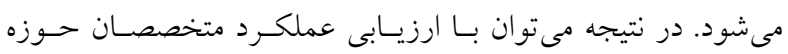


كرفته و تمامى مدارى و مقالات ايرانى كه در حوزههاى موضـوعى مربوطه و طى سالهاى مورد بررسى منتشر شدهاند، بازيـابى شــند. همجنين، اطلاعات مربوطه به توليدات علمى هر يكى از كشـورهاى برتر جهان به همين شكل در پِيخاه مربوطه صـورت گرفتـه اسـت.

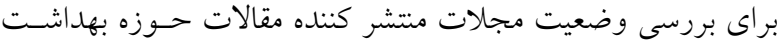

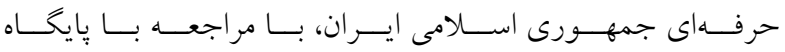

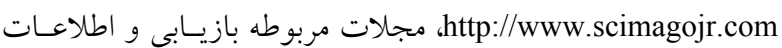

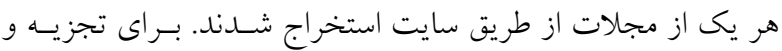
تحليل دادهها از نرم افزار آمارى SPSS و براى ترسيم شكلها از نرم افزار تحليل شبكه Node XL و نرم افزار VOSviewer استفاده شده

\section{يافته ها}

در شكل ا، رونـــ توليـات علمسى يزوهشــران و متخصصـان

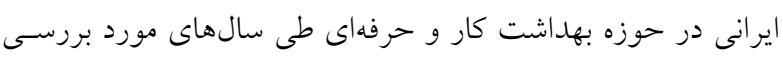
قابل مشاهده است.
يزوهشخران ايرانى در حــوزه بهداشـت حرفـهاى و تعيسين جايخـاه جمهورى اسلامى ايران در جهان صورت كرفته است.

\section{مواد و روش مها}

مطالعه حاضر به لحاظ هـدف، كـاربردى و بـه روش ييمايشىى توصيفى (با رويكـرد علـم سـنجى) صـورت گرفتـه اسـت. جامعـه يُزوهش مطالعه حاضر را تمامى مقالات و مدارك علمى نمايه شـده يزوهشخران كشورمان در حوزه بهداشـت كـار و حرفـهاى تشـكيل

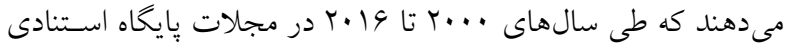
اسكويوس منتشر و نمايهسازى شدهاند. براى گردآورى اطلاعـات از

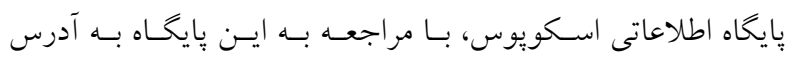
Affiliation " www.scopus.com country بازيابى شدند. در بخش دوم كار و براى گردآورى اطلاعات مربـوط

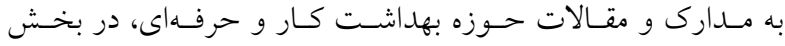
"Subject Area" انتخـاب و بـا (Professional Health and Occupational Health) محدود كردن سال "Year = 2000-2016" جستجوى نهايى صورت

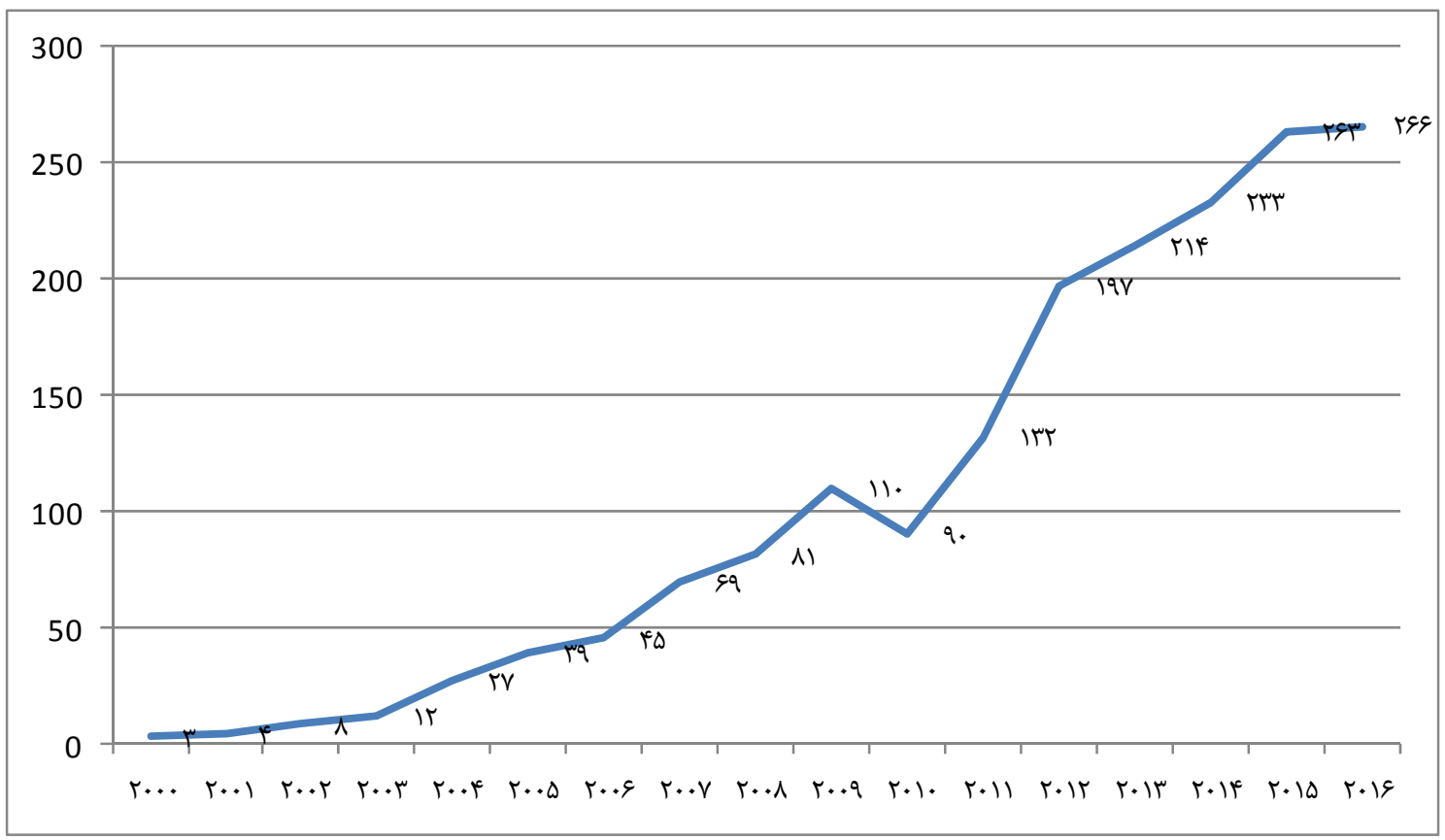

شكل ا: توليدات علمى بثوهشخران حوزه بهداشت حرفهاى جمهورى اسلامى ايران طى سالهاى مورد بررسى 


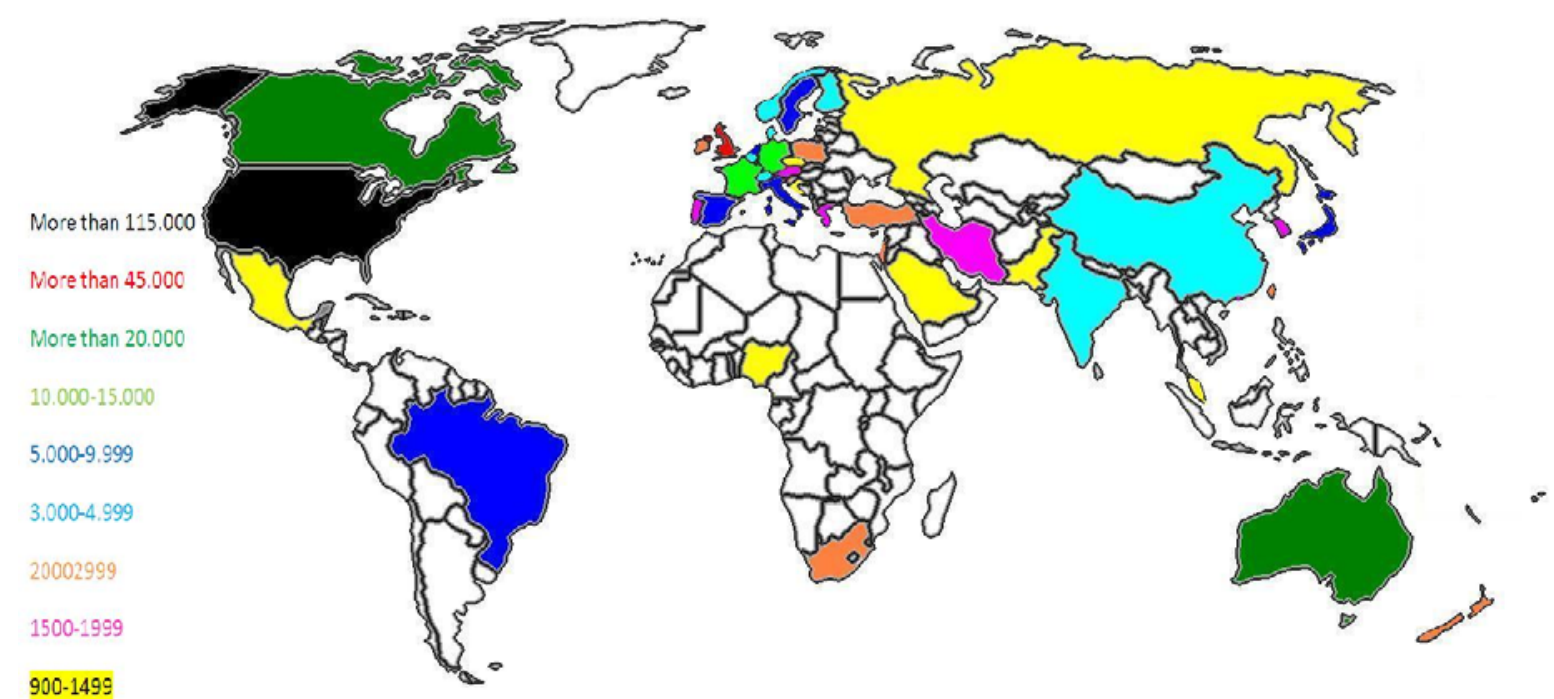

شكل ب: توليدات علمى كشورهاى مختلف جهان در حوزه بهداشت كار و حرفهاى طى سالهاى مورد بررسى

داشته است.

در جدول ا، نـام مراكز و دانشـاههـايى كـه بيشـترين تعـداد

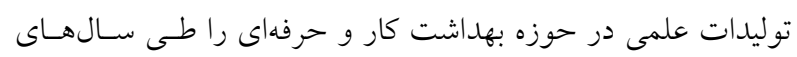
مورد بررسى منتشر نمودهاند، قابل مشاهده است.

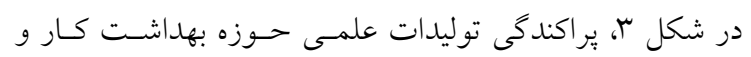

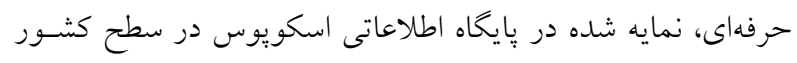
قابل مشاهده است.
در شكل ז، ميزان توليدات علمى حوزه بهداشت كار و حرفهاى كشورهاى مختلف دنيا قابل مشاهده مىباشد.

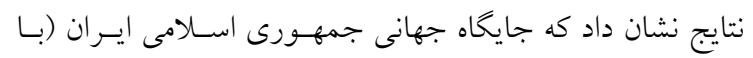

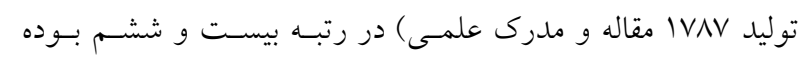

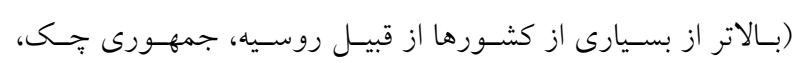

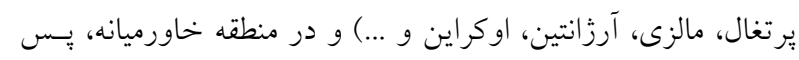
از تركيه و رزيم صهيونيستى در رتبه سوم قرار داشته است. در ميـان

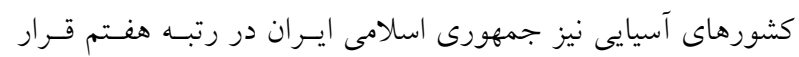

جدول ا: مر اكز و دانشخاههاى توليد كننده مدارى علمى جمهورى اسلامى ايران در حوزه بهداشت كار و حرفهاى

\begin{tabular}{|c|c|c|c|c|c|}
\hline تعداد توليدات علمى & نام دانشخاه / مركز & 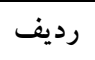 & تعداد توليدات علمى & نام دانشگاه / مركز & رديف \\
\hline Irr & دانشخاه تربيت مدرس & 4 & $9 \cdot 4$ & دانشگاه علوم يزشكى تهر ان & 1 \\
\hline$\wedge \mu$ & دانشخاه آزاد اسلامى & $v$ & rII & دانشخاه علوم يزشكى شهيد بهشتى & $r$ \\
\hline VA & دانشخاه علوم يزشكى همدان & $\wedge$ & 110 & دانشگاه علوم بزشكى شيراز & $r$ \\
\hline$v^{4}$ & دانشخاه علوم يزشكى مشهد & 9 & IYO & دانشگاه علوم يزشكى اصفهان & r \\
\hline 99 & دانشگاه علوم يزشكى تبريز & 1. & r. & دانشگاه علوم يزشكى ايران & 0 \\
\hline
\end{tabular}




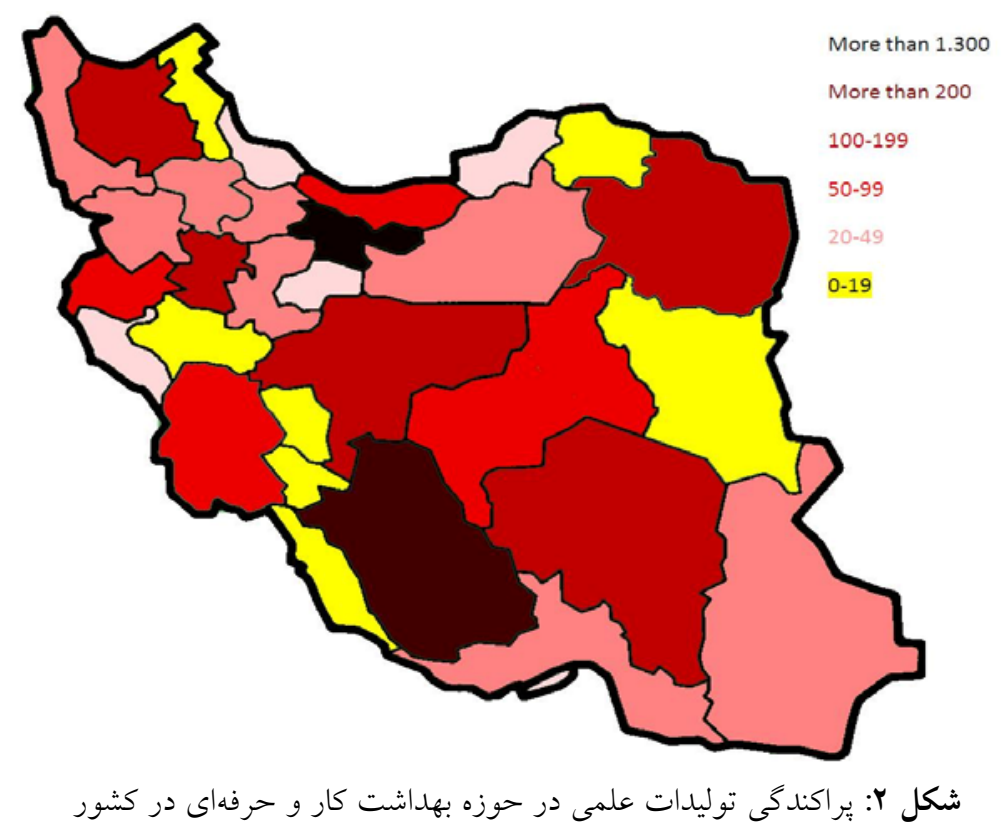

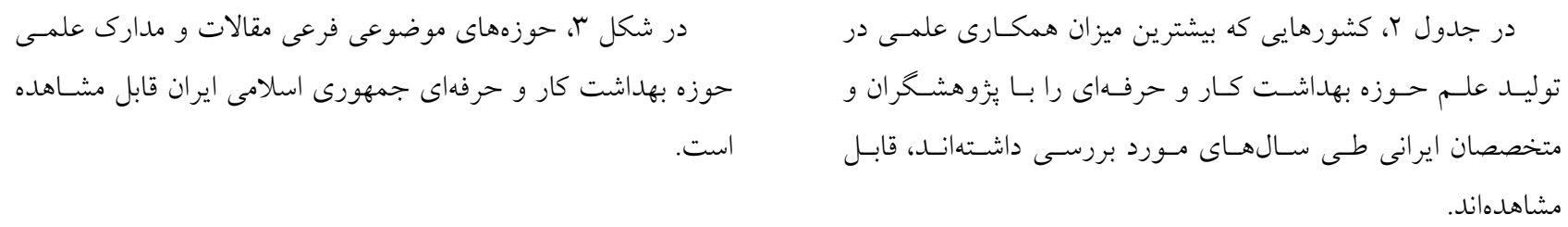

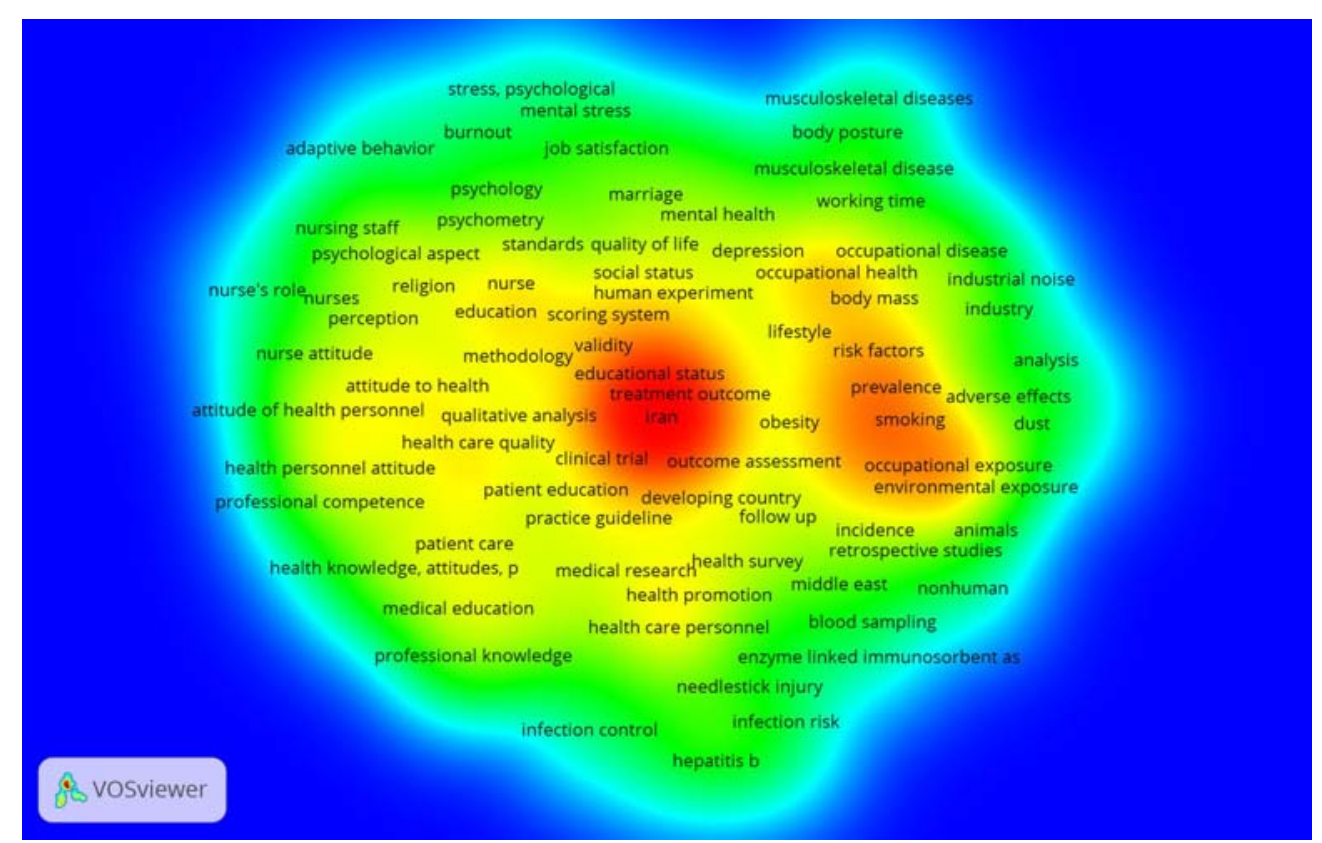

شكل r: شاخههاى فرعى توليدات علمى بزوهشخران ايرانى درحوزه بهاشت كار و حرفهاى 


\begin{tabular}{|c|c|c|c|c|c|}
\hline كانادا & سوئد & بريتانيا & استر اليا & امريكا & نام كشور \\
\hline 48 & qr & $\Lambda F$ & NF & $1 . r$ & تعداد توليدات \\
\hline فرانسه & آلمان & فنلاند & هلند & مالزى & نام كشور \\
\hline rI & rq & rq & זr & re & تعداد توليدات \\
\hline
\end{tabular}

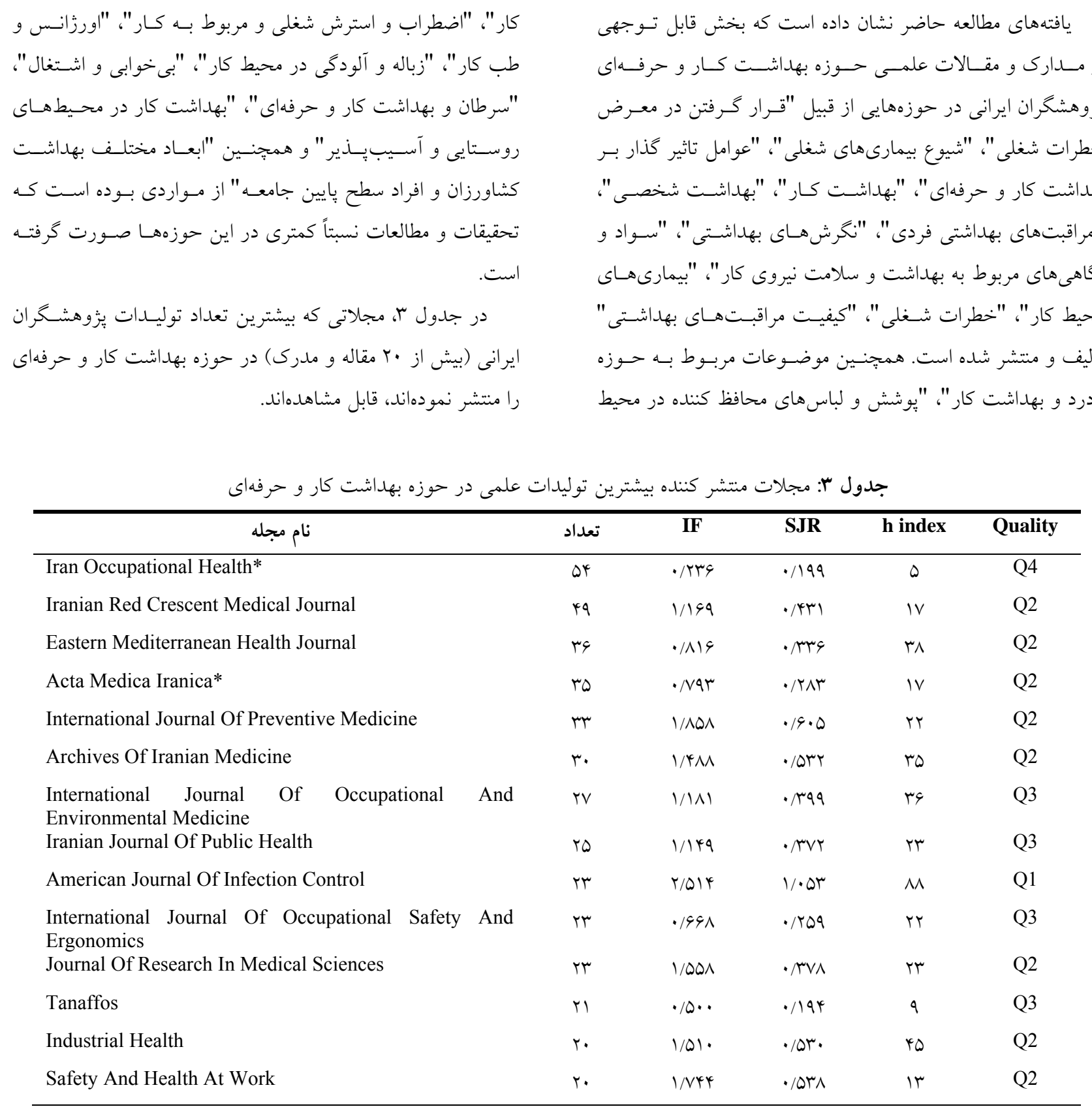




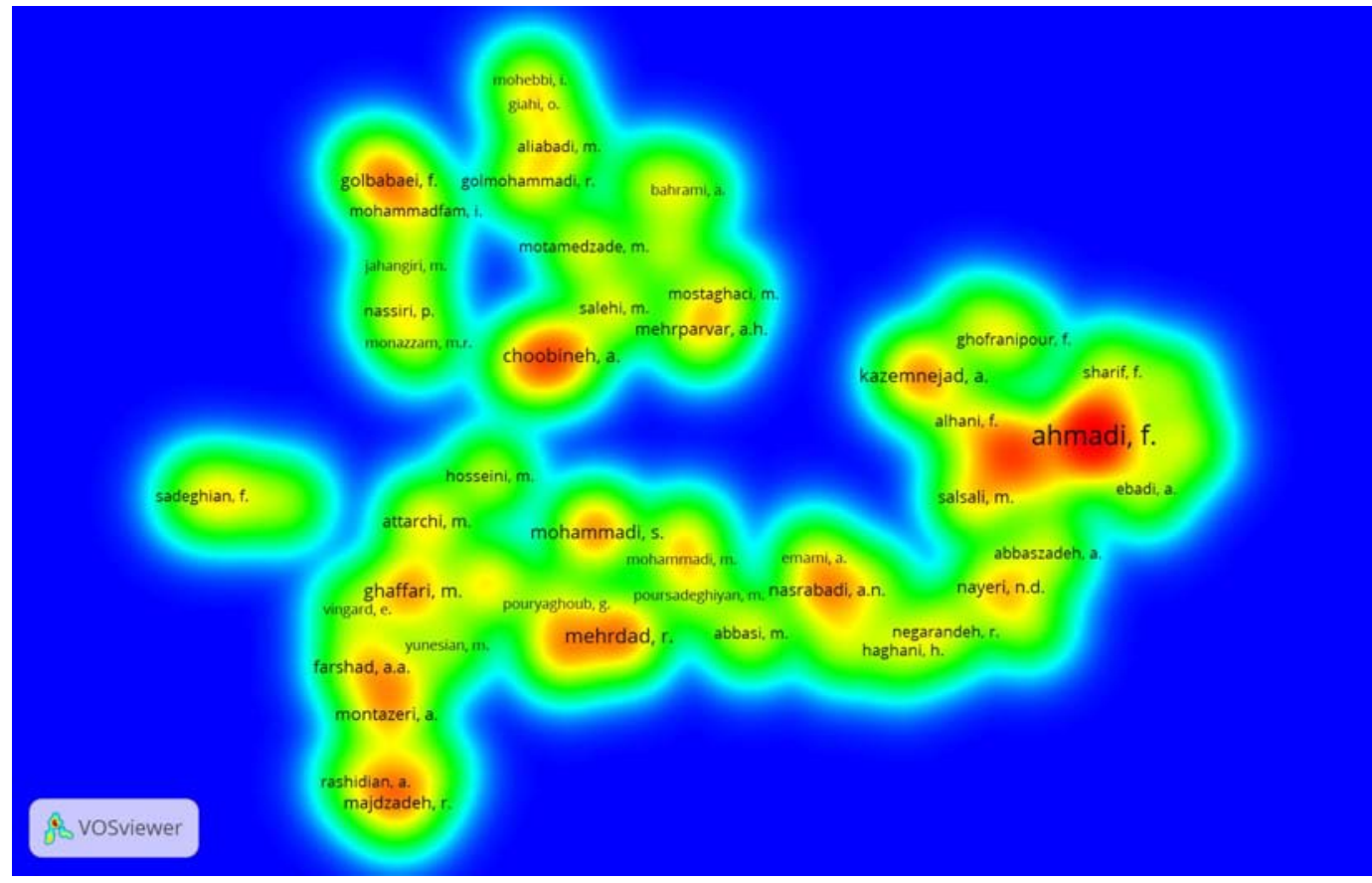

شكل †: نويسند گان و متخصصان يرتوليد كشورمان در حوزه بهداشت كار و حرفهاى طى سالهاى مورد بررسى

\section{بحث و نتيجه گيرى}

امروزه، اهميت صيانت از عوامل محيطى و نقش آن در ارتقـاى سطح سلامت جامعه و بالاخص نيروى انسانى قابل توجسه و بسـيار

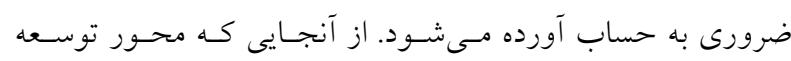
پايدار، نيروى كار سالم است و بـشى نيروى كار سـالم در محسيط

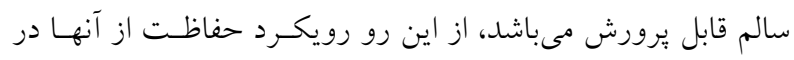

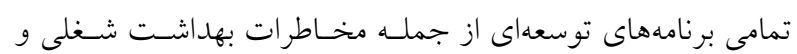
محيطى، اجتناب نايذير بنظر مىرسد. توجه به اين امر ما را بـر ايسن مى دارد كه در حسوزه بهداشـت محسيط و سـلامت نيـروى كـار بـهـ صورت عميق و دقيقتر مطالعات و تحقيقـات را بـا دقـت بيشـترى مورد بررسى قرار داده و در مسير تجزيه و تحليل مطالعات صـورت

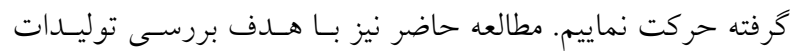
علمى جمهورى اسلامى ايران در حوزه بهداشت كـار و حرفـهاى و تعيين جايگاه بينالمللى كشورمان صورت گرفته است. يافتهاى بدست آمده از مطالعه حاضر نشـان داد كـه توليـدات

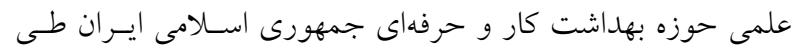

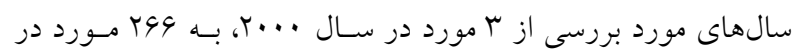

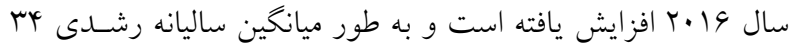

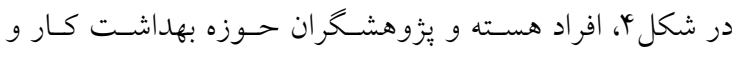
حرفهاى كشورمان كه بيشترين تعداد توليدات علمى راطى سالهاى مورد بررسى تاليف و منتشر نمودهاند، قابل مشاهدهاند.

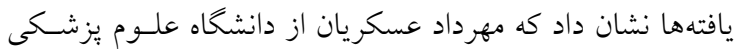

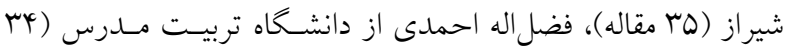

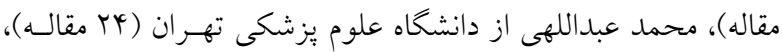
عيسى محمدى از دانشخاه تربيت مدرس (•r مقاله)، رامسين مهـرداد

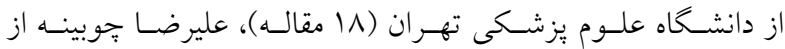
دانشخاه علوم يزشكى شيراز (1 1 مقالـه)، انوشـيروان كـاظم نـز اد از

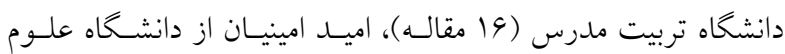
يزشكى تهران (4 أمقاله)، مصطفى غفارى از دانشگاه علوم يزشـكى

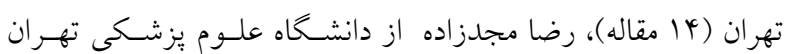

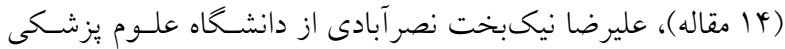
تهر ان (با مقاله)، فريده كل بابايى از دانشگاه علوم يزشـكى تهـران

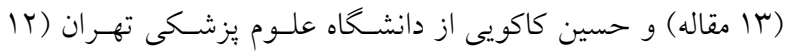

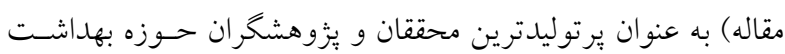
كار و حرفهاى كشورمان شناسايى شدهاند. 
بلدست آمله از مطالعه حاضر نيز نشان داده اسـت كـه بخـش قابـل

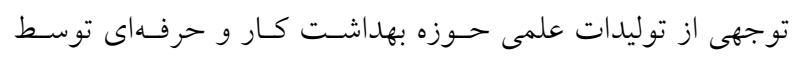
كشورهاى صنعتى جهان منتشر شدهاند و در اين ميان، ايالات متحده امريكا با توليد بيش از ها الهزار مقالـه و مـــرك علمسى، بيشـترين

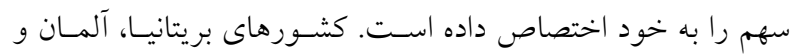

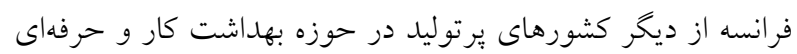

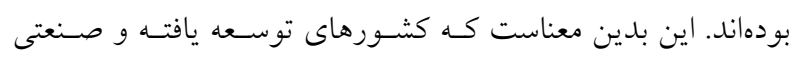
جهان، اهميت و ضرورت فعاليتهاى علمى و تحقيقـاتى در حسوزه بهلداشت كار و حرفهاى را در راستاى ارتقاى سطح سـلامت نيـروى كار درى كردهاند. مقايسه يافتهــاى مطالعـه حاضـر بــا بسـيارى از

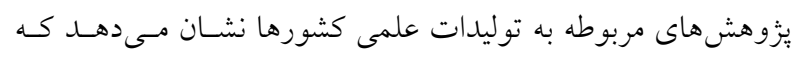

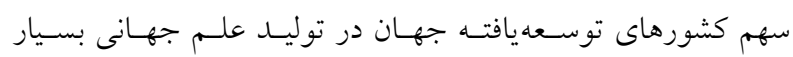

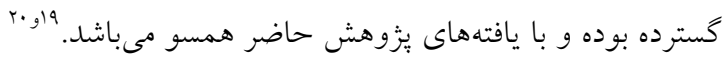

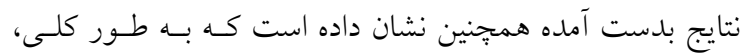

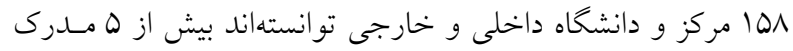
و مقاله علمى را طى سالهاى مورد بررسى منتشر نمايند. بعلاوه، از

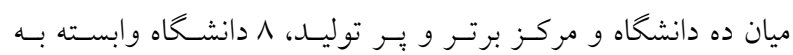

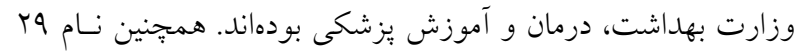

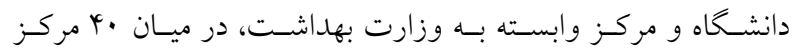

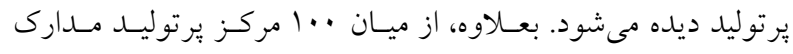

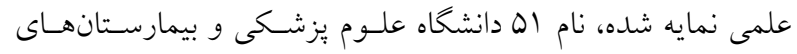

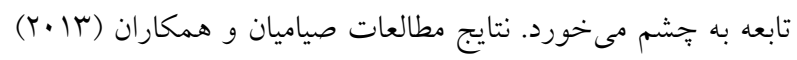

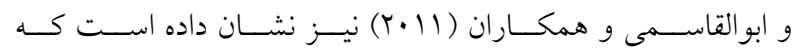

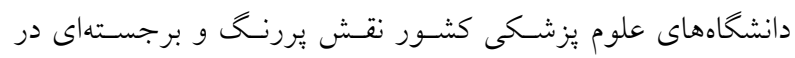

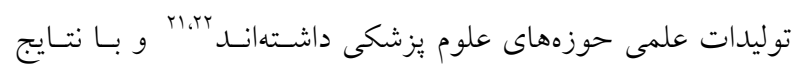
بلدست آمده از يزوهش حاضر همسو و همر استا مىباشد.

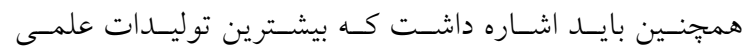
يزوهشخران كشورمان در سطح كشور، به ترتيب در شهرهاى تهران،

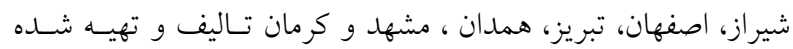

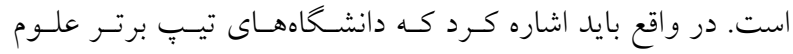

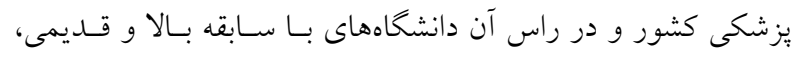
وجود كروهها و انجمنهاى علمى وتخصصى وابسته به آنها، بـالاتر

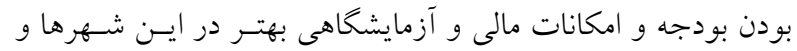
بسيارى از عو امل ديخر باعث شده اسـت كـه دانشـخاههـا و مراكـز

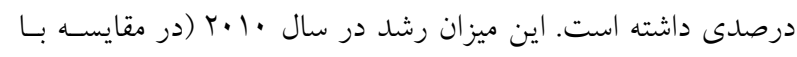

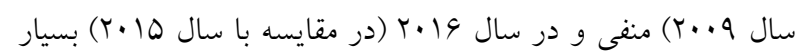
ناجير و در حدود ا درصد بوده است.همجنين بايد اشاره شود كـه. تعداد كل توليدات علمى جمهورى اسلامى ايران طى سالهاى مورد

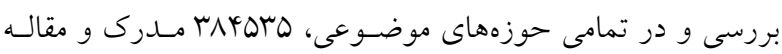

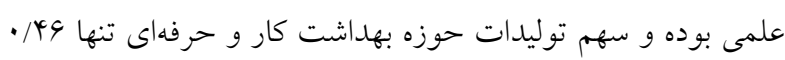
درصد مى باشد. همجنين يافتهاى بدست آمده از تجزيسه و تحليـل

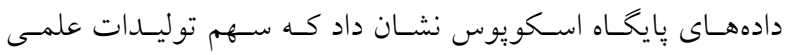
جمهورى اسلامى ايران در حوزه مورد بررسى در جهان، تنهـ هـ/.

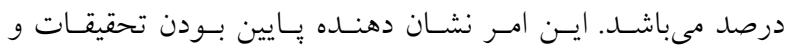
يزّوهشهـاى بيرامـون بهلداشـت كـار و حرفـهاى در كشـورمان در

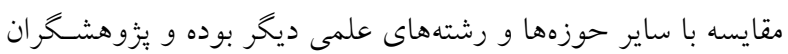
و متخصصان كشورمان در مقايسه با همتايان خارجىشان ضعيفتـر

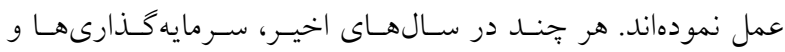

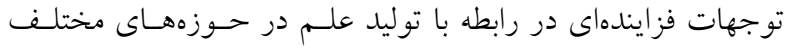
دانش و عرصه فناورى در كشورمان صورت گرفته و در حوزه علوم

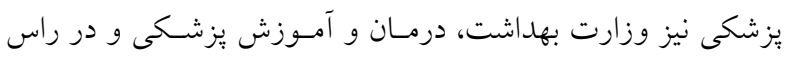
آن دولت و سازمانهـاى علمسى و يُزوهشسى اقـدامات و تمهيــات مناسب و مفيدى را تدوين و اجرا نمودهانـد، امـا بـهـ طـور كلى در حوزه بهاشت كار و حرفهاى، وضعيت توليـدات علمسى در سـطح مناسبى قرار نداشته است.

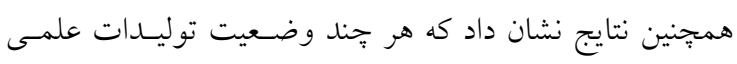
يُزوهشكران و متخخصان بهداشت كار و حرفـهاى در كشـورمان در سطح قابل قبولى قرار نداشته ، ولى رشد توليدات نسبتاً مطلوب و تا ترو حدودى قابل قبول بوده است. يافتههاى مطالعات رياحى و همكاران

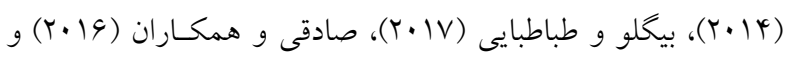

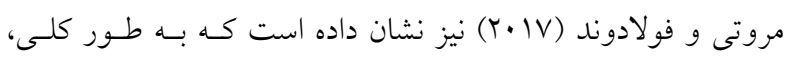
رشد توليدات علمى جمهورى اسـلامى ايــان در حـوزه يزشـكى و شاخههاى فرعى وابسته به آن بسيار زياد و قابل قبول بوده و با نتايج يزوهش حاضر همسو و همر استا مىباشد.

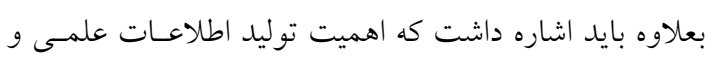
نقش انكار نايذير آن در توسعه پِايدار تا بدان حد است كه بسـيارى

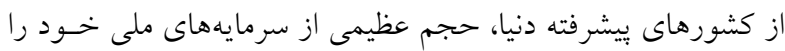
صرف توسعه يززوهش و موسسات بززوهشى مسىنماينـلـ. يافتسهــاى 
دانشخاه كشورمان توليد شده است و سهم دانشـاه علـوم بز شكىى

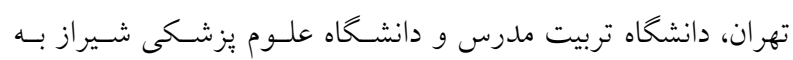

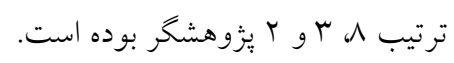
بر اساس يافتهاى مطالعه حاضر مىتوان اظهار نمود كه فراهم

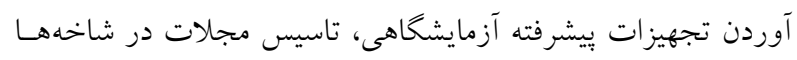

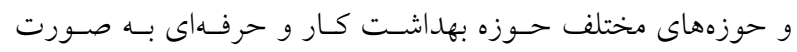
تخصصىى، كسـب اسـتانداردهاى لازم بـراى نمايسهسـازى آنها در

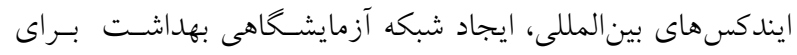
استفاده حداكثرى از تجهيزات موجود، عقد تفاهمنامه با مر اكز معتبر بين المللى در راستاى بروزهها و تحقيقات علمى مشترى مى تواند در

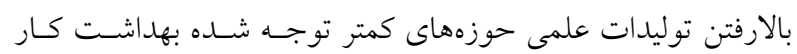

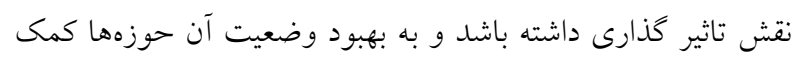
شايانى نمايد. بعلاوه بيشنهاد مى شود كه متخصصان و متوليـان ايـن

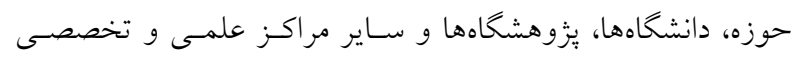

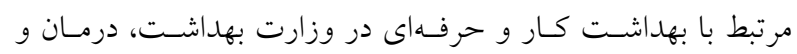

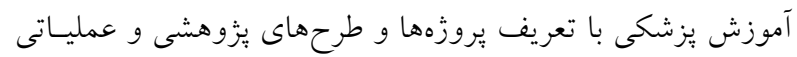

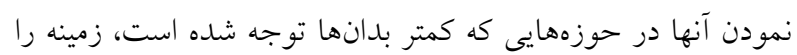
براى جاب و انتشار مقالات علمى در اين حوزهها فراهم آورند. در بايان مىتوان جنين جمع بندى نمود كه بخش قابـل تـوجهى

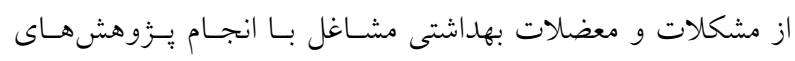

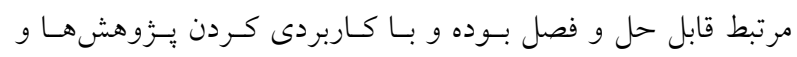

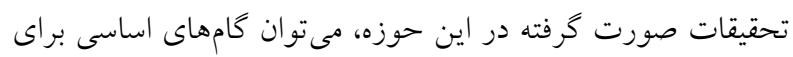
افزايش ايمنىسازى مشاغل برداشت. از آنجايى كه سـاليانه بسيارى

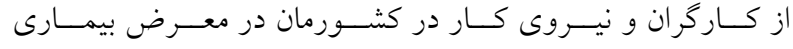

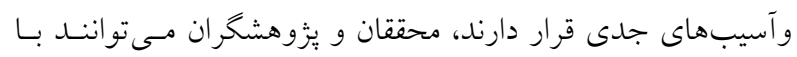

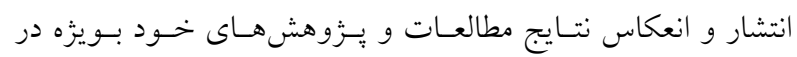

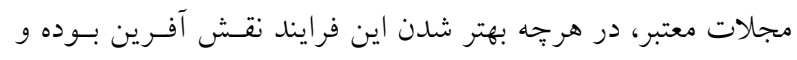

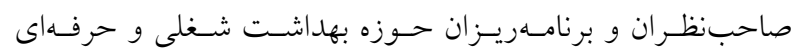

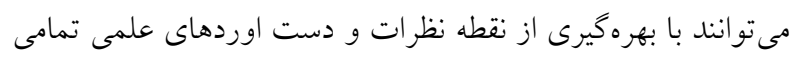

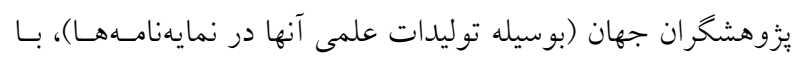

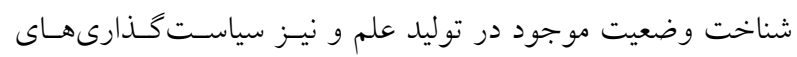

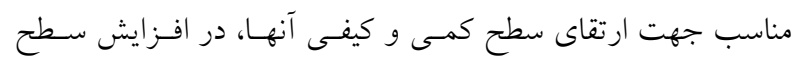
بهاشت و ايمنى افراد تاثير فراوانى داشته باشند.
آموزشى و ئزوهشى شـهرهاى ذكـر شـــه در مقايسـه بـا شهـرهاى

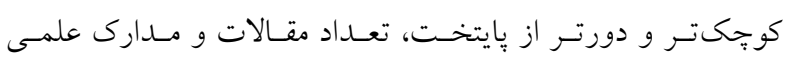

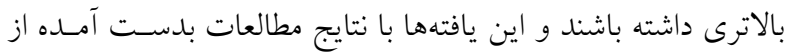

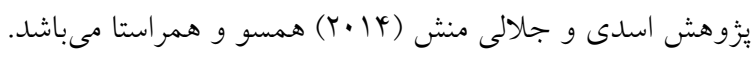

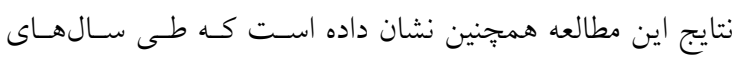

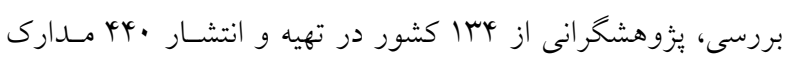

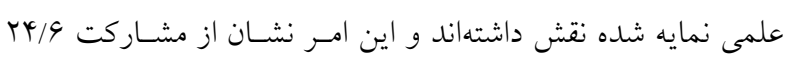

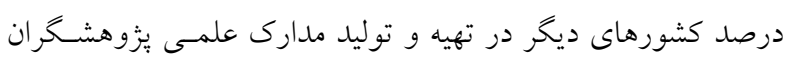

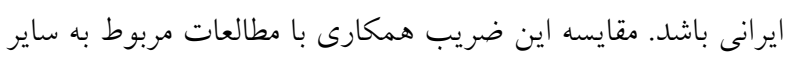

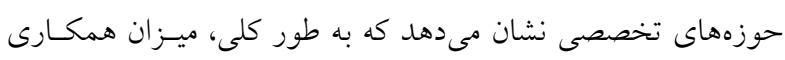

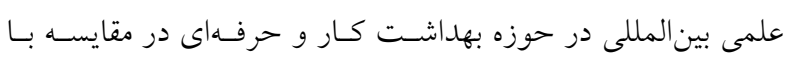

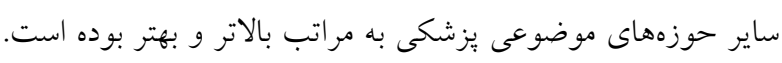

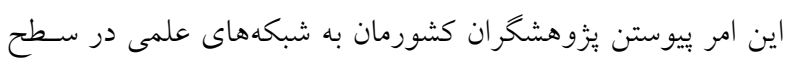

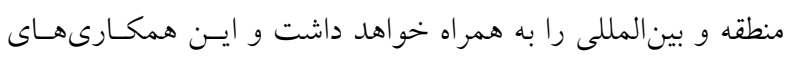

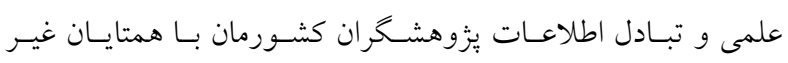

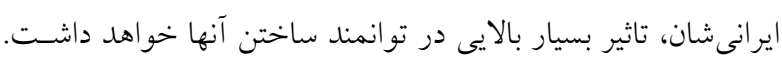

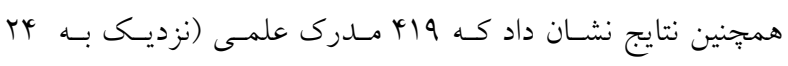

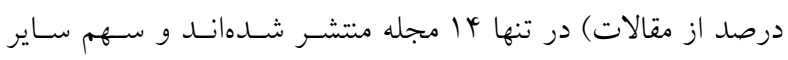

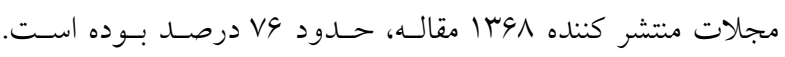

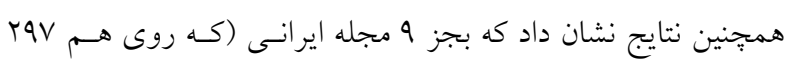

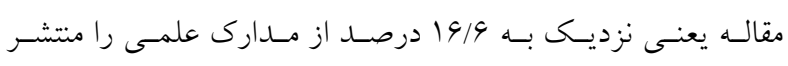

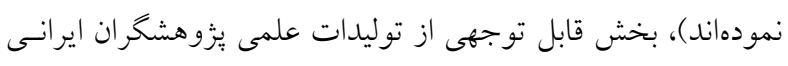

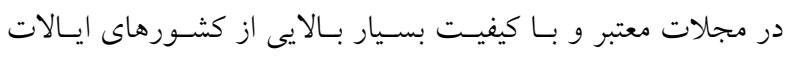

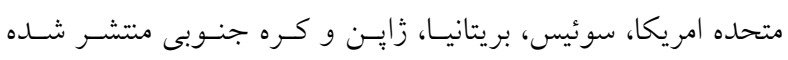

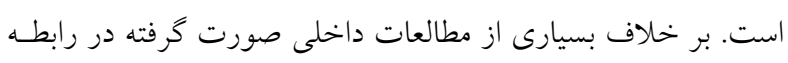

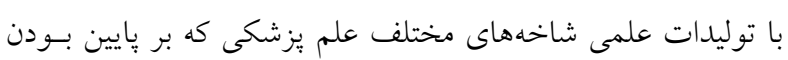

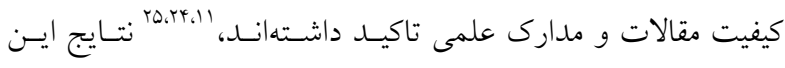

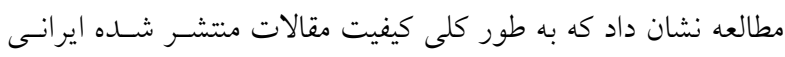

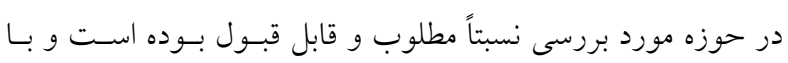
يزوهش هاى ديخر همسو و همر استا نمى باشد.

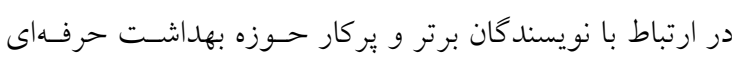

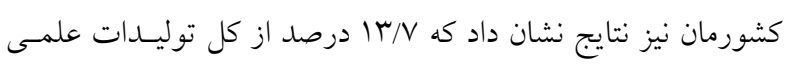

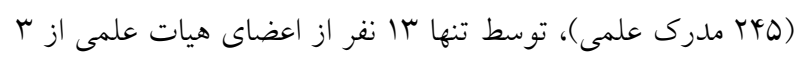




\section{References}

1. Soury Laky M, Habibi E, Rahmani N, Parsazadeh B, charkhandaz yeganeh R. Safety and Occupational health Risk assessment in a metal industry using Job Safety Analysis and William Fine methods. rsj. 2016; 2 (2) :1831.

2. Zaboli R, Tofighi SH, Valipour F, Hasani M. Effect of Occupational Health and Safety Management Standards and Environmental Management on Environmental Factors and Employees Satisfaction at MILAD Industrial Complex - Before and After Study.Journal of Nurse \& Physician Within War 3. 2014; 2 (2) :30-34

3. Mohammadfam E, Rahimi D, Mououdi M, Behzadi M. Evaluating Performance of Safety Management and Occupational Health Using Total Quality Safety Management Model (TQSM). TB. 2015; 14 (4) :23-35

4. Abootorabi SM, Mehrno H, Omidvari M. Proposing a model for safety risk assessment in the construction industry using gray multi - criterion decision- making. Journal of Health and Safety at Work. 2014;4(3):67- 74

5. Tirgar A, Samaei S E. Systematic analysis of a decade of occupational health research in Iran. Journal of Occupational Hygiene Engineering. Hamadan University of Medical Science 3. 2016; 3 (2) :47-55

6. Ardeshir A, maknoon $\mathrm{r}$, rekab eslami zadeh $\mathrm{m}$, jahantab z. Safety Risk Management effective on Occupational Health in High-rise Building construction projects with Fuzzy approach. Iran Occupational Health Journal. 2014;11(3):82-95

7. Hosseini M, Ramazani A, Tavasolian H, Mohsenzadeh M, Maleki S, Samimi K. Survey of knowledge and attitude of farmers of Southern Khorasan province regarding agriculture related OHS issues in 2008. ioh. 2011; 8 (1) :24-29

8. Ansari E, Vosoghi S. Investigation the effects of economics - safety performance indices changes on average of lost work days (case study in the project refinery installation). ioh. 2016; 12 (6) :98-107

9. Karami G, Bijani M, Salamat E. Agricultural experts' safety knowledge toward work with agricultural machinery in south west of Iran. Journal of Occupational Hygiene Engineering. Hamadan University of Medical Science 3. 2015; 1 (4) :30-39

10. Foroughi Z, Janbabaei G, Alizadeh-Navaei R, Hedayatizadeh-Omran A, Eslami M, Geraili B, et al . Iranian Cancer Research Outputs: A Scientometric Study. J Mazandaran Univ Med Sci. 2017; 26 (146) :206-211

11. Riahi A, Siamian H, Zareh A, Alizadeh Navaei R, Haghshenas M R. Quantitative Evaluation of Scientific Productions in Iran in Immunology and Microbiology Indexed in Scopus Database (2000-2012). J Mazandaran Univ Med Sci. 2014; 24 (118):205-213.[In Persian]

12. Biglu M, Tabatabaie S S. Gastrointestinal cancers in Iran: Iranian scientists approach to gastrointestinal cancers researches in international databases. koomesh. 2017; 19

\section{(1) :1-9.[In Persian]}

13. Sedghi S, Mousakhani G, Talachi H. Citation Analysis and Scientific Mapping of Iranian Researchers' Publications in Stem Cell Indexed in Science Citation Index Up to 2015. jha. 2016; 19 (66) :7-19

14. Morovati M, Fooladvand Z. Scientific Outputs of Iranian Researchers in Lupus Field in Scopus (1983-2015). JRUMS. 2017; 15 (9) :875-884

15. Rostami Dovom M, Ramezani Tehrani F, Nazeri P, Alamdari S, Azzizi F. Using a Scientific Map to Compare Scientific Publications on Poly Cystic Ovary Syndrome in Iran, Middle East and Other Countries. Iranian Journal of Endocrinology and Metabolism. 2016; 18 (4) :287-296

16. Falavigna A, Botelho RV, Teles AR, da Silva PG, Martins D, Guyot JP, Gonzalez AS, Avila JM, Defino HL. Twelve years of scientific production on Medline by Latin American spine surgeons. PloS one. 2014;9(2):e87945.

17. Huamaní C, De Castro JR, González-Alcaide G, Polesel DN, Tufik S, Andersen ML. Scientific research in obstructive sleep apnea syndrome: bibliometric analysis in SCOPUS, 1991-2012. Sleep and Breathing. 2015;19(1):109-14.

18. Yayc1 F, Deren S, Yayc1 E. A bibliometric analysis of global scientific production on cesarean and anesthesia. Cumhuriyet Medical Journal. 2014;36(2):214-20.

19. Riahi A, Rod MA, Ahmadi E. Iran's Scientific Interactions and Communications with the G8 Countries. Collnet Journal of Scientometrics and Information Management. 2014;8(2):217-25.

20. Abazari Z, Riahi A, Sohbatiha F, Siamian H, Yamin Firoz M. A comparative study of medical journals and articles growth in eastern mediterranean regional office member countries. Journal of Payavard Salamat. 2015;9(3):23548. [In Persian]

21. Siamian H, Firooz MY, Vahedi M, Aligolbandi K. Scientific Production of medical sciences universities in North of Iran. Acta Informatica Medica. 2013; 21(2):113.

22. Riahi A, Siamian H, Zare A, Yaminfirooz M. Mapping the Scientific Productions of Mazandaran University of Medical Sciences in Scopus Database in 1992-2013. J Mazandaran Univ Med Sci. 2015; 24 (122) :395-400.[In Persian]

23. Asadi S, Jalalimanesh A. Mapping and Visualization of the Distribution of Scientific Wealth in Iran. Journal of Information Processing and Management. 2014; 28 (4) : 917-943

24. Gohari M R, Salehi M, Vahabi N, Bazrafshan A. Analysis Of Medical Sciences Articles Structure Quality During 2002-2008. payavard. 2012; 6 (1) :79-88.[In Persian]

25. Khalili M, Rahmatpour P, Barari F, Hoseinzadeh T. Scientific Outputs of Guilan University of Medical Sciences in Scopus Database Based on Scientometrics Indicators. J of Guilan Univ of Med Sci 2016; 25(98):916. [In Persian] 